\title{
Increasing long jump performance through plyometric exercises
}

\author{
Tjung Hauw $\operatorname{Sin}^{1 *}$, Budi Indra Ruslin ${ }^{2}$ \\ ${ }^{12}$ Universitas Negeri Padang, Indonesia \\ ${ }^{*}$ Corresponding author, $\equiv$ e-mail: thj_sin@yahoo.com
}

\begin{abstract}
Low athlete's long jump performance is attributed to the unsystematic training approach. Therefore, this study aimed to determine the effect of plyometric training on athlete performance. It was a quasi-experiment comprising of 32 athletes who were selected through purposive sampling. The instrument used in the long jump test is under the standard of the Indonesian Athletics Association (PASI), and the data analysis used a t-test. The results of the data analysis showed significant differences in athlete performance before and after plyometric training. This study recommends adjusting athletes' long jump performance using Plyometric Exercises.
\end{abstract}

Keyword: Plymometrik Exercise, and Long Jump

How to Cite: Sin, T., \& Ruslin, B. (2019). Increasing Long Jump Performance Through Plyometric Exercises. COUNS-EDU: The International Journal of Counseling and Education, 4(2), 88-93. DOI: https://doi.org/10.23916/0020190420920

\section{Introduction}

Long jump is one of athletic sports widely carried out in the community. According to (Iswandi \& Purnomo, 2013; Church et al., 2017), long jump is a type of jump number alongside infectious, high, and pole jumps. In this study, jump away involves moving the whole body from certain points by running then rejecting, floating in the air, and landing (Thompson, 2019; Fraser et al., 2019). Generally, it is a movement that requires jump lifting of legs upfront while in the air by making repulsion on one leg to reach the far distance (Later, 2017a; Organism et al., 2019). It is an athletic number that combines speed, strength, and agility to land as far as possible from the point of repulsion (Iswandi \& Purnomo, 2013; Qi et al., 2019).

Long jump is divided into four phases, including prefix, repulsion, drift, and landing (Yadav \& Paris, 2014; Michailidis, Tabouris, \& Metaxas, 2019). Prefix is the initial movement in the form of running to gain the speed for repulsion or jumping. According to (Yadav \& Uparosiya, 2014), the purpose of the prefix is to accelerate to a maximum controlled speed when taking off. The higher speed at taking off helps to move to a long distance. The speed attained from the prefix is called horizontal speed and it provides strength for upward repulsion upfront (Stojanović, Ristić, McMaster, \& Milanović, 2017; Wyss et al., 2019).

In this study, the squat style long jump number is discussed. According to (Ballesteros, 1993; Church et al., 2017) Squat long jump result from horizontal velocities during prefix with vertical power from the strength of the repulsive leg. In this athletic sport, the implementation of the activity begins with a quick run prefix and then jumping with a body lift movement from one point to another. The techniques in this athletic branch are grouped into several stages (Kariyala, Hobara, \& Zushi, 2018; El-Asher, Hassan, Taiar, \& Tipp, 2019). 
The repulsion or pedestal is a rapid movement between running, starting and floating (Dissent, 1992; Asadi, Ramirez-Campillo, Arazi, \& SeAZ de Villarreal, 2018). According to (Hafiz, Arwin, \& Shorten, a. a.), footstool or repulsion of the foot needs to be strong to achieve sufficient jump height without losing the forward speed. The purpose of repulsion is to create a vertical impulse through the center of gravity while maintaining balance and control, and involves placing the foot with the knee bent for repulsion with the leg straight. This process is enhanced by lifting the arms and legs (Yadav \& Paris, 2014). The repulsion distance is the horizontal length between the prefix line and the jump repulsion board when flying. The jumper distance starts at the center of the moving mass from take off to Jump landing (Wakai \& Linthorpe, 2005; Kim et al., 2018).

The jumper needs to reach the furthest distance by not losing body balance when landing (Dissent, 1992; Stojanovic et al., 2017; Wilke et al., 2019). The main goal is to avoid falling back into the pit. Essentially, the pit measures leap from the location where the body contacts the sand closest to the take off point (Yadav \& Paris, 2014; Karcher \& Buchheit, 2017). When jumping at a low take off angle, there is a high horizontal speed at landing. For this reason, the feet can be far in front of the body without the risk of falling backward. (Lutheran, N. P., Guzman, M. S., \& Bridgett, 2005) (Marchant, Griffith, Partridge, Beesley, \& Porter, 2018; Tufano et al., 2018). One might appear to be falling backward and to prevent this, the point of weight needs to be brought to the front by bending for the body and knees to dock. Several factors influence the ability of a jumper, including speed, explosive strength of leg muscles, flexibility and coordination of motion (Yani, 2015; Seattle, phylogeny, Koski, Ojanen, \& Carolinian, 2019; Cohen \& Negra, 2017).

Plyometric training is often used in connecting repetitive jump and movements or stretch strain reflexes from the muscles to produce explosive reactions (Radcliffe, J., \& Farentino, 2015; Beato, Bianchi, Cortella, Merlini, \& Durst, 2018). This is based on the plyometric training on individual prerequisites (Froelich, M., Felder, H., \&amp; Reuter, 2014). It is important to ensure that the level of stimulation and scope of training does not cause very tight artificial structures. The long jump performance increase during the simulation competition when the oligomeric conditioning exercise is carried out 3 minutes before each experiment. This improvement is attributed to the progressive increase in the vertical speed of takeoff, while there is no effect on horizontal speed (Bodanis, G. C., Tsokkos, A., \& valgus, a. a.; Whitehead, Schett, Michigan, \& Martin, 2018; McKinlay et al., 2018).

Depth jump exercise refers to the training which starts with standing on a high gymnastic box (65$75 \mathrm{~cm}$ ), falling to the mat on the floor with two legs, and jumping upfront before returning to the top of the box to for the next jump. This activity is often carried out in the determined stimulus (Radcliffe, J., \& Farentino, 2015; Silva, Neiva, Marques, Izquierdo, \& Marinho, 2018). Depth jump training requires one to jump down as fast as possible. It is similar to a long jump where after starting the prefix the student makes a repulsion on the board and jumps as far as possible. It is supposed to be conducted to improve jumping ability (Earp, Newton, Cormie, \& Blazevich, 2017; Settle et al., 2019).

\section{Method}

This was a quasi-experiment focusing on the difference in the long jump performance of athletes in SMP Negeri 3 Batang Kapas after being subjected to plyometric exercises. The population involved 58 students, though 32 were selected through purposive sampling technique. The preliminary data was obtained by measuring the ability of athletes of State Junior High School 3 Batang Kapas with a long jump test under the standards union of every Indonesian athletic (PASI). Each exercise was conducted in 16 meetings with a frequency of three times a week and a duration of 60 minutes per meeting. After a plyometric exercise, the final test out with the long jump test was conducted. This was meant to determine the difference in the increase in students' abilities after taking part in the training (Negra et al., 2017). Ttest was used to analyze the data as a prerequisite for the analysis of the normality test with the piliform and the variance homogeneity tests with the $\mathrm{F}$ test at the confidence levels $\mathrm{a}=0.05$.

\section{Results and Discussions}


Based on the experimental research design, there are two groups of data described separately.

Table 1. Long Jump Performance Data Pretest- Posttest after plyometric

\begin{tabular}{ccccccc}
\hline No & Group & N & Highest score & Lowest score & Average & $\begin{array}{c}\text { Standard } \\
\text { Deviation }\end{array}$ \\
\hline $\mathbf{1}$ & Pretest & 32 & 400 & 320 & 350,31 & 22,91 \\
$\mathbf{2}$ & Posttest & 32 & 410 & 320 & 374,66 & 22,53 \\
\hline
\end{tabular}

Table 1 shows an increase in scores before and after since the high score increased by 10 points. The average score also increased. The distribution of long jump performance data is described in the frequency distribution table below:

Table 2. Distribution of long jump performance data

\begin{tabular}{ccccc}
\hline Interval Class & Pretest & Percentage & Posttest & Percentage \\
\hline $\mathbf{( 3 2 0 - 3 3 5 )}$ & 9 & $28.13 \%$ & 2 & $6.25 \%$ \\
$\mathbf{( 3 3 6 - 3 5 1 )}$ & 13 & $40.63 \%$ & 6 & $18.75 \%$ \\
$\mathbf{( 3 5 2}-\mathbf{3 6 7 )}$ & 2 & $6.25 \%$ & 5 & $15.63 \%$ \\
$\mathbf{( 3 6 8 - 3 8 3 )}$ & 4 & $12.50 \%$ & 6 & $18.75 \%$ \\
$\mathbf{( 3 8 4 - 3 9 9 )}$ & 2 & $6.25 \%$ & 6 & $18.75 \%$ \\
$(\mathbf{4 0 0}-\mathbf{4 1 5 )}$ & 2 & $6.25 \%$ & 7 & $21.88 \%$ \\
Total & 32 & & 32 & \\
\hline
\end{tabular}

Table 2 shows the long jump performance improved between before and after the training. The difference is in the pretest and posttest columns, where the interval class increases significantly in the posttest, proving that Plyometric training improves long jump performance.

The frequency distribution of achievement motivation scores can also be seen in the diagram below:

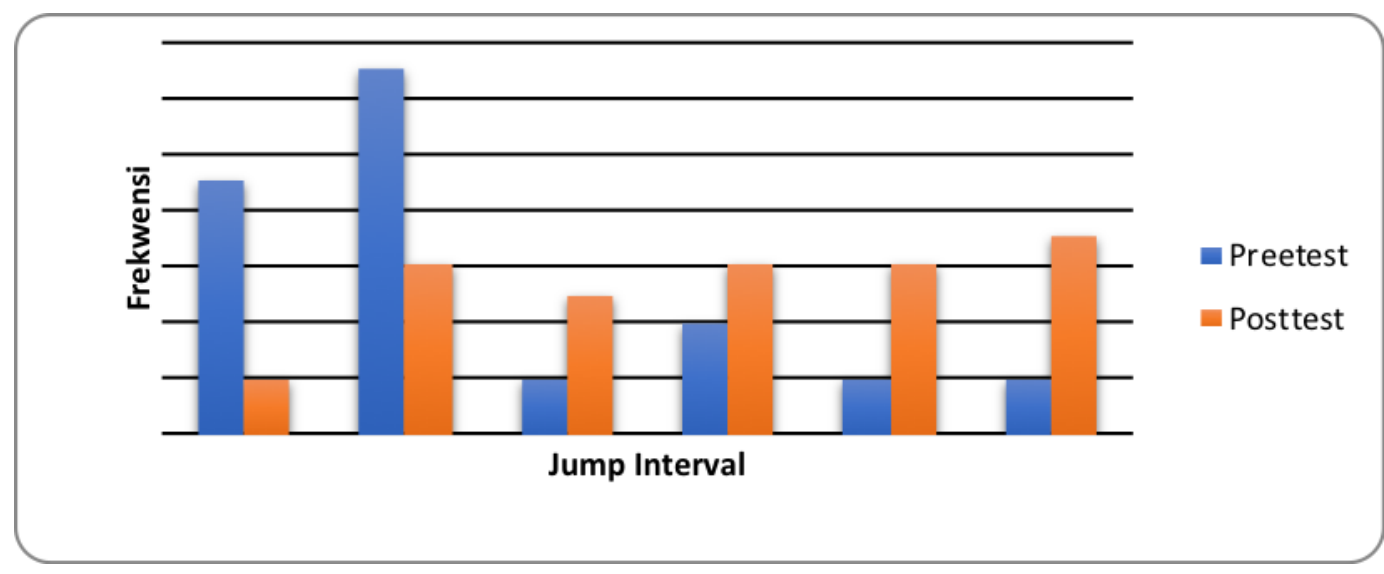

Picture 1. Long jump performance chart

As an analysis prerequisite test, normality and homogeneity were conducted. The normality test in the two groups of pretest and posttest data is normally distributed while the homogeneity test results of all analysis groups show they were homogeneous. Research hypothesis testing used a $t$-test with $a=0.05$. The 
results of the analysis of the hypothesis show 1) there are significant differences in the long jump performance before and after a plyometric exercise; 2) the athlete's long jump performance after a plyometric training is better than before the training.

A good and appropriate form of training is an important thing a trainer needs to choose and design since it affects the athlete's long jump ability. Plyometric exercises increase the explosive power. This study used depth jump training, which is the most popular form of limb Plyometric exercise meant to develop the ability of explosive limb muscles. In case it is good and correct, it produces maximum leg muscle strength. During the long jump, explosive power is a very supportive physical condition and increases the long jump ability if it is good.

\section{Conclusions}

From this study, the following conclusions are drawn 1) There are significant differences in long jump performance before and after plyometric exercises; 2) The athlete's performed better after plyometric training than before the training. To improve performance, a plyometric needs to be used.

\section{Acknowledgments}

This study received a lot of help and guidance from various parties. The authors express gratitude to Dr. Yulkifli, M. Si, Dr. Syahrastani, M. Kes, AIFO, and Dr. Willadi Rasyid, M. Pd, as contributors, Afriyati, S. Pd, as the Principal of SMP Negeri 3 Batang Kapas, and Amir Faisal, S.Pd dan Andri Syahputra, S.Pd as teachers of education and extracurricular trainers at SMP Negeri 3 Batang Kapas.

\section{References}

Adisasmita, Y. (1992). Olahraga pilihan atletik. Jakarta: Depdikbud.

Asadi, A., Ramirez-Campillo, R., Arazi, H., \& Sáez de Villarreal, E. (2018). The effects of maturation on jumping ability and sprint adaptations to plyometric training in youth soccer players. Journal of Sports Sciences, 36(21), 2405-2411. https://doi.org/10.1080/02640414.2018.1459151

Ballesteros, J. M. (1993). Pedoman Dasar Melatih Atletik. Jakarta: Program Pendidikan \& Sistem Sertifikasi Pelatih Atletik. Persatuan Atletik Seluruh Indonesia.

Beato, M., Bianchi, M., Coratella, G., Merlini, M., \& Drust, B. (2018). Effects of Plyometric and Directional Training on Speed and Jump Performance in Elite Youth Soccer Players. Journal of Strength and Conditioning Research, 32(2), 289-296. https://doi.org/10.1519/JSC.0000000000002371

Bogdanis, G. C., Tsoukos, A., \& Veligekas, P. (n.d.). Improvement of Long-Jump Performance During Competition Using a Plyometric Exercise. International Journal of Sports Physiology and Performance, 12(2), 235.

Bogdanis, G. C., Tsoukos, A., Methenitis, S. K., Selima, E., Veligekas, P., \& Terzis, G. (2019). Effects of low volume isometric leg press complex training at two knee angles on force-angle relationship and rate of force development. European Journal of Sport Science, 19(3), 345-353. https://doi.org/10.1080/17461391.2018.1510989

Chaabene, H., \& Negra, Y. (2017). The effect of plyometric training volume on athletic performance in prepubertal male soccer players. International Journal of Sports Physiology and Performance, 12(9), 12051211. https://doi.org/10.1123/ijspp.2016-0372

Chu, D. A. (1998). Jumping Into Plyometrics. California:Leisure Press.

Earp, J. E., Newton, R. U., Cormie, P., \& Blazevich, A. J. (2017). The Influence of External Load on Quadriceps Muscle and Tendon Dynamics during Jumping. Medicine and Science in Sports and Exercise, 49(11), 2250-2259. https://doi.org/10.1249/MSS.0000000000001361

El-Ashker, S., Hassan, A., Taiar, R., \& Tilp, M. (2019). Long jump training emphasizing plyometric exercises is more effective than traditional long jump training: A randomized controlled trial. Journal of Human Sport and Exercise, 14(1), 215-224. https://doi.org/10.14198/jhse.2019.141.18

Fraser, B. J., Blizzard, L., Tomkinson, G. R., Lycett, K., Wake, M., Burgner, D., ... Magnussen, C. G. (2019). The great leap backward: changes in the jumping performance of Australian children aged 11-12-years between 1985 and 2015. Journal of Sports Sciences, 37(7), 748-754. https://doi.org/10.1080/02640414.2018.1523672

Iswandi, F., \& Purnomo, E. (2013). Hubungan Sprint Dan Daya Ledak Otot Tungkai Terhadap Hasil 
Lompat Jauh gaya jongkok. Jurnal Pendidikan Dan Pembelajaran, 2(4).

Karcher, C., \& Buchheit, M. (2017). Shooting performance and fly time in highly trained wing handball players: Not everything is as it seems. International Journal of Sports Physiology and Performance, 12(3), 322-328. https://doi.org/10.1123/ijspp.2016-0055

Kariyama, Y., Hobara, H., \& Zushi, K. (2018). The Effect of Increasing Jump Steps on Stance Leg Joint Kinetics in Bounding. International Journal of Sports Medicine, 39(9), 661-667. https://doi.org/10.1055/a-0633-9308

Kavanaugh, A. A., Mizuguchi, S., Sands, W. A., Ramsey, M. W., \& Stone, M. H. (2018). Long-term changes in jump performance and maximum strength in a cohort of national collegiate athletic association division i women's volleyball athletes. Journal of Strength and Conditioning Research, 32(1), 66-75. https://doi.org/10.1519/JSC.0000000000002214

Linthorne, N. P., Guzman, M. S., \& Bridgett, L. A. (2005). Optimum take-off angle in the long jump. . Journal of Sports Sciences, 23(7), 703.

Marchant, D. C., Griffiths, G., Partridge, J. A., Belsley, L., \& Porter, J. M. (2018). The Influence of External Focus Instruction Characteristics on Children's Motor Performance. Research Quarterly for Exercise and Sport, 89(4), 418-428. https://doi.org/10.1080/02701367.2018.1512075

McKinlay, B. J., Wallace, P., Dotan, R., Long, D., Tokuno, C., Gabriel, D. A., \& Falk, B. (2018). Effects of plyometric and resistance training on muscle strength, explosiveness, and neuromuscular function in young adolescent soccer players. Journal of Strength and Conditioning Research, 32(11), 3039-3050. https://doi.org/10.1519/JSC.0000000000002428

Michailidis, Y., Tabouris, A., \& Metaxas, T. (2019). Effects of plyometric and directional training on physical fitness parameters in youth soccer players. International Journal of Sports Physiology and Performance, 14(3), 392-398. https://doi.org/10.1123/ijspp.2018-0545

Negra, Y., Chaabene, H., Sammoud, S., Bouguezzi, R., Abbes, M. A., Hachana, Y., \& Granacher, U. (2017). Effects of Plyometric Training on Physical Fitness in Prepuberal Soccer Athletes. International Journal of Sports Medicine, 38(5), 370-377. https://doi.org/10.1055/s-0042-122337

Qi, F., Kong, Z., Xiao, T., Leong, K., Zschorlich, V. R., \& Zou, L. (2019). Effects of combined training on physical fitness and anthropometric measures among boys aged 8 to 12 years in the physical education setting. Sustainability (Switzerland), 11(5). https://doi.org/10.3390/su11051219

Radcliffe, J., \& Farentinos, R. (2015). High-Powered Plyometrics,. 2E. Human Kinetics.

Ramirez-Campillo, R., Álvarez, C., García-Hermoso, A., Ramírez-Vélez, R., Gentil, P., Asadi, A., ... Izquierdo, M. (2018). Methodological Characteristics and Future Directions for Plyometric Jump Training Research: A Scoping Review. Sports Medicine, 48(5), 1059-1081. https://doi.org/10.1007/s40279-018-0870-z

Santtila, M., Pihlainen, K., Koski, H., Ojanen, T., \& Kyröläinen, H. (2019). Physical Fitness and Body Anthropometrics Profiles of the Female Recruits Entering to Voluntary Military Service. Military Medicine, 184(1-2), E200-E205. https://doi.org/10.1093/milmed/usy145

Silva, L. M., Neiva, H. P., Marques, M. C., Izquierdo, M., \& Marinho, D. A. (2018). Effects of WarmUp, Post-Warm-Up, and Re-Warm-Up Strategies on Explosive Efforts in Team Sports: A Systematic Review. Sports Medicine, 48(10), 2285-2299. https://doi.org/10.1007/s40279-018-0958-5

Stojanović, E., Ristić, V., McMaster, D. T., \& Milanović, Z. (2017). Effect of Plyometric Training on Vertical Jump Performance in Female Athletes: A Systematic Review and Meta-Analysis. Sports Medicine, 47(5), 975-986. https://doi.org/10.1007/s40279-016-0634-6

Thompson, B. J. (2019). Does work-induced fatigue accumulate across three compressed 12 hour shifts in hospital nurses and aides? PLoS ONE, 14(2). https://doi.org/10.1371/journal.pone.0211715

Tufano, J. J., Malecek, J., Steffl, M., Stastny, P., Hojka, V., \& Vetrovsky, T. (2018). Field-based and labbased assisted jumping: Unveiling the testing and training implications. Frontiers in Physiology, 9(SEP). https://doi.org/10.3389/fphys.2018.01284

Varanoske, A. N., Wells, A. J., Kozlowski, G. J., Gepner, Y., Frosti, C. L., Boffey, D., ... Hoffman, J. R. (2018). Effects of $\beta$-alanine supplementation on physical performance, cognition, endocrine function, and inflammation during a $24 \mathrm{~h}$ simulated military operation. Physiological Reports, 6(24). https://doi.org/10.14814/phy2.13938

Wakai, M., \& Linthorne, N. P. (2005). Optimum take-off angle in the standing long jump. Human Movement Science, 24(1), 81-96.

Wang, C.-C., Fang, C.-C., Lee, Y.-H., Yang, M.-T., \& Chan, K.-H. (2018). Effects of 4-week creatine 
supplementation combined with complex training on muscle damage and sport performance. Nutrients, 10(11). https://doi.org/10.3390/nu10111640

Whitehead, M. T., Scheett, T. P., McGuigan, M. R., \& Martin, A. V. (2018). A comparison of the effects of short-term plyometric and resistance training on lower-body muscular performance. Journal of Strength and Conditioning Research, 2743-2749. https://doi.org/10.1519/JSC.0000000000002083

Wilke, J., Kaiser, S., Niederer, D., Kalo, K., Engeroff, T., Morath, C., .. Banzer, W. (2019). Effects of high-intensity functional circuit training on motor function and sport motivation in healthy, inactive adults. Scandinavian Journal of Medicine and Science in Sports, 29(1), 144-153. https://doi.org/10.1111/sms.13313

Wyss, T., Roos, L., Studer, F., Mäder, U., Beuchat, C., \& Staub, K. (2019). Development of physical fitness performance in young Swiss men from 2006 to 2015. Scandinavian Journal of Medicine and Science in Sports, 29(4), 586-596. https://doi.org/10.1111/sms.13376

Yadav, M., \& Uparosiya, N. (2014). Survey on MANET: Routing protocols, advantages, problems and security. International Journal of Innovative Computer Science \& Engineering, 1(2), 12-17.

Yani, A. (2015). Pengaruh Metode Latihan Sirkuit, Metode Konvensional dan Motivasi Berprestasi Terhadap Kemampuan Lompat Jauh Gaya Jongkok. Primary: Jurnal Pendidikan Guru Sekolah Dasar, 4(2), 134-.

Yusutria, M. A. (2017a). Profesionalisme Guru Dalam Meningkatkan Kualitas Sumber Daya Manusia. Curricula: Journal of Teaching and Learning, 2(1).

Yusutria, M. A. (2017b). Profesionalisme Guru Dalam Meningkatkan Kualitas Sumber Daya Manusia. ,. Curricula: Journal of Teaching and Learning, 2(1).

Zarei, M., Namazi, P., Abbasi, H., Noruzyan, M., Mahmoodzade, S., \& Seifbarghi, T. (2018). The effect of ten-week FIFA $11+$ injury prevention program for kids on performance and fitness of adolescent soccer players. Asian Journal of Sports Medicine, 9(3). https://doi.org/10.5812/asjsm.61013 